Comparative Zoology.

When the Blue Jay was first pubished by Mrs. Priestly in 1942, Frank Baines was one of the select group if 75 original subscribers. Many of iis notes appeared in the first two volumes, including participation in he first annual Saskatchewan Christnas Bird Count. Later contributions o the Blue Jay expressed his concern about the decline of the Sharp-tailed Grouse and his article of remiiscences of the early days, entitled "Then and Now", appeared in the Golden Jubilee Museum Issue of Sepember 1955 (13:23-25). A more comlete account of his experiences in the arly days appeared in two instalnents in the Yorkton Enterprise on March 18 and July 8, 1948.

He organized the Saltcoats and Disrict Conservation Society on August 0 , 1954, which affiliated with the askatchewan Natural History Soiety. That year the Saltcoats society rganized 29 observers in 12 groups to over 10 different rural school disricts on the Christmas Bird Count; is sons Dave and Walter and sons-inaw Jim Rooke and Glen Laycock par- ticipated, together with several of his grandchildren. Ten nailkeg nest boxes were placed around Anderson Lake, Saltcoats in 1955 and at least two were used by Goldeneye ducks in 1956 and 1957. Although the Society "petered out" after two years, Frank Baines continued a vigorous outdoorsman until well beyond his 80th birthday, attended annual meetings of the provincial society and contributed to the program on at least two occasions.

His son, Elwin K. Baines, Tisdale apiarist, is a past Vice-President of the Saskatchewan Natural History Society and Phil, President of the Saskatoon S.P.C.A., is also a member. Dave, on the home farm, passes on significant bird observations each year.

How appropriate that our Saskatchewan Museum of Natural History in Regina was dedicated in Jubilee Year "to the honour of all the pioneers who came from many lands to settle in this part of Canada - a tribute to their vision, toil and courage which gave so much to Saskatchewan and this nation."

\title{
BRIEF NOTES ON CERTAIN ANIMALS OF THE CRESCENT LAKE DISTRICT, SASKATCHEWAN, SINCE 1883
}

\section{by the late Frank Baines}

n $1950 \mathrm{Mr}$. Baines, the pioneer to whom the bove tribute was written, commented on some $f$ the animals in that region. Included in his emarks was information on the changes in bundance of certain species. Since records of istorical distribution are rare and so of parcular interest, his comments are reproduced ere.

\section{tar-nosed Mole}

Condylura cristata):

I believe we trapped a Star-nosed Mole about 1915 on SE1 29-23-3 W2, hile catching "gophers".

\section{nowshoe Rabbit}

Lepus americanus):

These hares were abundant in 1883 nd formed the main item of our diet he first winter. Their numbers have ince decreased, but they are still ommon.

\section{White-tailed Jack Rabbit}

(Lepus townsendii):

Jack rabbits were rather uncommon in the 1880's, but have been common since about 1900 .

Woodchuck (Marmota monax):

No woodchucks were seen until about 1915, but now they are an uncommon but consistent resident.

Beaver (Castor canadensis):

The first beaver noted in the district came to the Cutarm Creek in the 1920's, and resided there until trapped illegally a few years ago. A new pair have since been planted there by the Department of Natural Resources.

Wandering individuals have also 
been seen: about 1924 one was observed on NW 20-23-3 W2, going upstream; an island on NW 30-23-3 showed beaver teeth marks on the trees; one lived for three years on NE 4-23-3.

Norway Rat (Rattus norvegicus):

The first rat seen was caught by hounds about 1928, and have increased in numbers since.

Arctic Fox (Alopex lagopus):

About 1924 an Arctic Fox was caught by a neighbour's dog.

Red Fox (Vulpes vulpes):

Red foxes were quite common in the early days. I believe there were four or five pairs resident on our home section in 1883 , and up to 10 pairs per section south of Boakeview School. About 1920 they disappeared for some years. Now an occasional one is seen. Wolverine (Gulo luscus):

One was seen when hunting deer at Crescent Lake about 1920. I thought the track must be that of a lynx and followed it to where the wolverine was curled asleep on the sunny side of some balsam poplars. He dived for cover as I shot and missed him.

Badger (Taxidea taxus):

Badgers were plentiful in the
1880 's, then almost disappeared after the turn of the century.

Lynx (Lynx canadensis):

An occasional stray came into the district. One that had been treed by Indian dogs was shot in the 1890's.

Wapti (Cervus canadensis):

Elk were said to have been present in the 1870's. In the 1880's antlers were found, but no animals were seen. Tracks were seen north of Saltcoats once, about 1920 .

Mule Deer (Odocoileus hemionus):

Mule Deer were fairly common in 1883 , although not as common as the White-tailed Deer are now. They always paused to look ait the hunter before they would run and hence were easy to shoot. None are seen now.

\section{White-tailed Deer}

(Odocoileus virginianus):

No White-tailed Deer were present until 1896. They became common about 1910, and increased in number as the country became settled.

Bison (Bison bison):

No bison were left by 1883 , though great quantities of buffalo bones indicated that they had been numerous not too long before.

\section{MACQUARIE ISLAND $54^{\circ}$ SOUTH}

by Bill Merilees, Castlegar, British Columbia

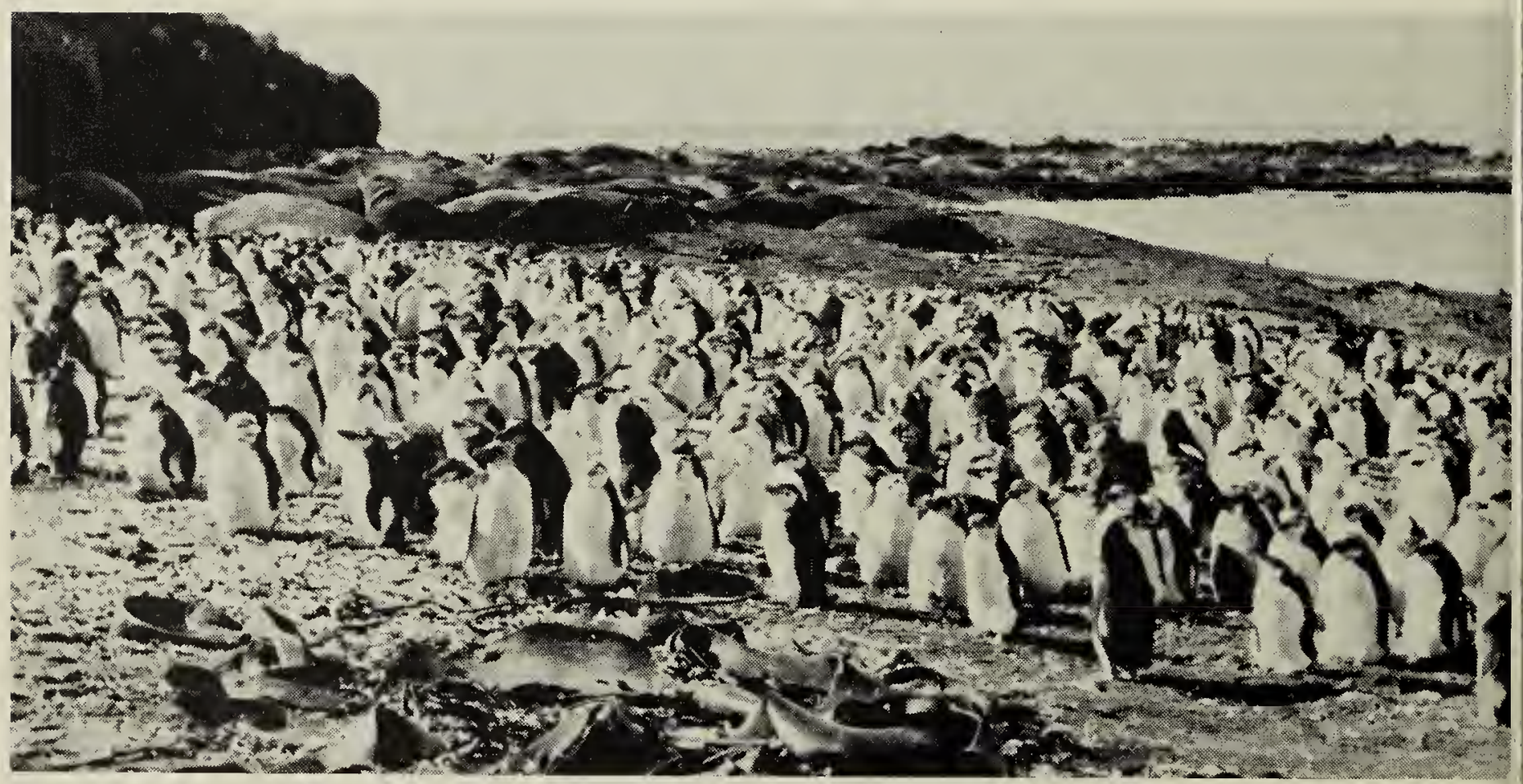

Royal Penguin "sit in". Elephant Seals in background. 